\title{
EDITORIAL
}

\section{Steroid sulfation research has come a long way}

\author{
Jon Wolf Mueller and Paul A Foster \\ Institute of Metabolism and Systems Research, University of Birmingham, Birmingham, UK \\ Correspondence should be addressed to J W Mueller: j.w.mueller@bham.ac.uk or to P A Foster: p.a.foster@bham.ac.uk
}

Making and breaking conjugates of sulfate with highly biologically potent steroid hormones was discussed from various angles at SUPA2017, Targeting Steroid Sulfation Pathways. This Themed Scientific Meeting was held 23-25 April 2017, at the Medical School at the University of Birmingham, UK. This research field has come a long way since enzymatic sulfation of steroids was first described in 1955 (De Meio et al. 1955). Since then, scientific perspectives on why sulfated steroids exist have changed several times. Initially, sulfation was seen as a mere solubilization step readying these steroid forms for renal secretion. It took until the mid-2000s and the work by Michael Reed to suggest that sulfated steroids represent a circulating pool of steroid precursors that are bioavailable for cellular desulfation and thus fueling downstream steroid signaling (Reed et al. 2005). We have recently provided a comprehensive review on the dynamic interplay of steroid sulfation and desulfation and highlighted the impact of these pathways on normal physiology and on a multitude of disease states (Mueller et al. 2015). We also indicated where we lack knowledge on many aspects of steroid sulfation and desulfation.

Thus, at SUPA2017, we welcomed about 50 participants with affiliations from 11 different nations to discuss these unknowns. The high intake of high-profile speakers from so many countries was only possible due to the generous support from the Society for Endocrinology (UK) via a Themed Scientific Meeting grant. Further, we were fortunate to be able to reach out to several pharmaceutical and scientific companies through support by a Medical Research Council (UK) Proximity-to-Discovery grant. This mixture provided unique opportunities for updates on the key advancements in this rapidly moving field, which we have tried to capture in this special issue.

The steroid sulfation theme currently experiences growing research interest, which is adding novel insights about PAPS synthase and sulfotransferase function, novel analytics for steroid conjugate quantification and ripening drug development strategies (Foster \& Mueller 2018). These strategies mainly target the steroid sulfatase enzyme with several compounds in development and in clinical trials (Potter 2018). Novel analytical approaches allow for detection and quantification of the previously neglected doubly sulfated steroid disulfates (Pozo et al. 2018), with the biological function of these disulfates to be better understood in the near future. The role of the steroid sulfatase pathway in the estrogen-dependent etiology and pathology of endometriosis is reviewed (Piccinato et al. 2018), highlighting targeting estrogen action as a potential therapy. Further, original research shows novel insights into the contribution of steroid sulfatase to the intracrine regulation of decidualization (Gibson et al. 2018).

Sulfated steroids can also have roles within the central nervous system and the influence of steroid sulfatase on brain function, behavior and mental health during pregnancy is reviewed here (Davies 2018). High levels of circulating DHEA sulfate of adrenal origin may be unique to humans and great apes; however, porcine steroid metabolism is unique as Leydig cells can produce noticeable quantities of sulfated estrogens with high SULT1E1 expression detected in the epididymal head (Schuler et al. 2018). Interestingly, the expression of SULT2A1 and other steroidogenic enzymes was detected in porcine testis (Zimmer et al. 2018). A study about possible benefits of a sulfated resveratrol derivative may lead toward biotechnological applications of sulfation pathways (Correia-da-Silva et al. 2018). A scholarly review about the many and diverse marine sulfated steroids completes this special issue (Carvalhal et al. 2018); certainly, out there are many more sulfated compounds to discover and to make use in biotechnological applications.

SUPA2017 was a high-profile and focused meeting of steroid sulfation researchers from around the globe and 


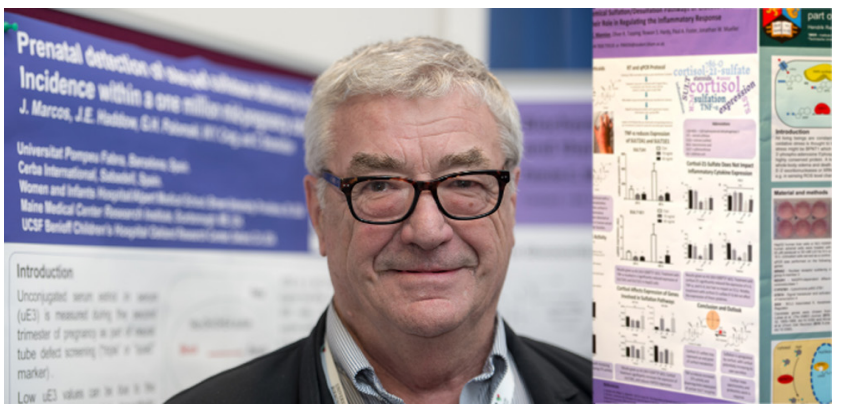

Figure 1

Dr Shackleton published about steroid sulfates already in 1968 and now in this special issue. (Image NickRobinsonPhoto.com).

from various disciplines. Interactions were at least as dynamic as previously described for PAPS synthases (Schroder et al. 2012, Mueller et al. 2018). Conference attendees with various different backgrounds could understand each other and exchanged views. Understanding in this growing field might be enhanced further by using uniform nomenclature for sulfation reactions; sulfonation is a misleading term (Mueller \& Muller 2016).

The meeting came to a close with a short award ceremony: we acknowledged that the best talk selected from the submitted abstracts was provided by Marta Correia-da-Silva. Considering that another conference participant, Cedric Shackleton (Fig. 1), had already published a paper mentioning steroid sulfates in March 1968 (Shackleton et al. 1968), 50 years ago, we affirmed him to have 'the longest sulfation pathway'. Finally, we fondly remember SUPA2015, our first SUPA conference in 2015 (Mueller \& Muller 2016) and do look forward to similar meetings in the future.

\section{Declaration of interest}

The authors declare that there is no conflict of interest that could be perceived as prejudicing the impartiality of this editorial.

\section{Funding}

The authors would like to thank the Society for Endocrinology for the awarding of the SfE Themed Scientific Meeting grant, and the MRC for the awarding of the Proximity-to-Discovery grant. These grant funds were assigned to the SUPA2017 meeting costs only.

\section{References}

Carvalhal F, Correia-da-Silva M, Sousa E, Pinto M \& Kijjoa A 2018 Sources and biological activities of marine sulfated steroids. Journal of Molecular Endocrinology 61 T211-T231. (https://doi.org/10.1530/ JME17-0252)

Correia-da-Silva M, Rocha V, Marques C, Deus CM, Marques-Carvalho A, Oliveira PJ, Palmeira A, Pinto M, Sousa E, Sousa Lobo JM, et al. 2018 Potential benefits of a sulfated resveratrol derivative for topical application. Journal of Molecular Endocrinology 61 M29-M41. (https:// doi.org/10.1530/JME18-0031)

Davies W 2018 The steroid sulfate axis and its relationship to maternal behavior and mental health. Journal of Molecular Endocrinology $\mathbf{6 1}$ T119-T210. (https://doi.org/10.1530/JME17-0219)

De Meio RH, Wizerkaniuk M \& Schreibman I 1955 Enzymatic system synthesizing sulfuric acid esters of phenols. Journal of Biological Chemistry 213 439-443.

Foster PA \& Mueller JW 2018 Insights into steroid sulfation and desulfation pathways. Journal of Molecular Endocrinology 61 T273-T285. (https://doi.org/10.1530/JME18-0086)

Gibson DA, Foster PA, Simitsidellis I, Critchley HOD, Kelepouri O, Collins F \& Saunders PTK 2018 A role for steroid sulfatase in intracrine regulation of endometrial decidualisation. Journal of Molecular Endocrinology 61 M50-M68. (https://doi.org/10.1530/ JME18-0037)

Mueller JW \& Muller S 2016 Welcome to a SUPA issue. Chemico-Biological Interactions 259 1. (https://doi.org/10.1016/j.cbi.2016.11.006)

Mueller JW, Gilligan LC, Idkowiak J, Arlt W \& Foster PA 2015 The regulation of steroid action by sulfation and desulfation. Endocrine Reviews 36 526-563. (https://doi.org/10.1210/er.2015-1036)

Mueller J W, Idkowiak J, Gesteira T F, Vallet C, Hardman R, van den Boom J, Dhir V, Knauer S K, Rosta E \& Arlt W 2018 Human DHEA sulfation requires direct interaction between PAPS synthase 2 and DHEA sulfotransferase SULT2A1. Journal of Biological Chemistry 293 9724-9735. (https://doi.org/10.1074/jbc.RA118.002248)

Piccinato CA, Malvezzi H, Gibson DA \& Saunders PTK 2018 Contribution of intracrine oestrogens to the etiology of endometriosis. Journal of Molecular Endocrinology 61 T253-T271. (https://doi.org/10.1530/JME17-0297)

Potter BVL 2018 Steroid sulfatase inhibition by aryl sulfamates: clinical progress, mechanism and future prospects. Journal of Molecular Endocrinology 61 T233-T252. (https://doi.org/10.1530/JME18-0045)

Pozo OJ, Marcos J, Khymenets O, Pranata A, Fitzgerald CC, McLeod MD \& Shackleton C 2018 Alternate steroid sulfation pathways targeted by LC-MS/MS analysis of disulfates: application to prenatal diagnosis of steroid synthesis disorders. Journal of Molecular Endocrinology $\mathbf{6 1}$ M1-M13. (https://doi.org/10.1530/JME17-0286)

Reed MJ, Purohit A, Woo LW, Newman SP \& Potter BV 2005 Steroid sulfatase: molecular biology, regulation, and inhibition. Endocrine Reviews 26 171-202.

Schroder E, Gebel L, Eremeev AA, Morgner J, Grum D, Knauer SK, Bayer P \& Mueller JW 2012 Human PAPS synthase isoforms are dynamically regulated enzymes with access to nucleus and cytoplasm. PLOS ONE 7 e29559. (https://doi.org/10.1371/journal. pone.0029559)

Schuler G, Dezhkam Y, Tenbusch L, Klymiuk MC, Zimmer B \& Hoffmann B 2018 Formation and hydrolysis of sulfonated estrogens in the porcine testis and epididymis. Journal of Molecular Endocrinology 61 M15-M27. (https://doi.org/10.1530/JME17-0245)

Shackleton CH, Livingstone JR \& Mitchell FL 1968 The conjugated 17-hydroxy epimers of delta5-androstene-3beta-17-diol in infant and adult urine and umbilical cord plasma. Steroids 11 299-311.

Zimmer B, Tenbusch L, Klymiuk MC, Dezhkam Y \& Schuler G 2018 Expression of SULT2A1, SULT2B1 and HSD3B1 in the porcine testis and epididymis. Journal of Molecular Endocrinology 61 M43-M57. (https://doi.org/10.1530/JME17-0277)

Received in final form 3 May 2018

Accepted 16 May 2018 http://jme.endocrinology-journals.org https://doi.org/10.1530/JME-18-0109 (c) 2018 Society for Endocrinology Published by Bioscientifica Ltd. Printed in Great Britain 